\title{
Analgesic activity of Momordica cochinchinensis and Momordica balsamina fruit extracts
}

\author{
Mohan R. Agrawal ${ }^{1 *}$, Anilkumar N. Aher ${ }^{2}$, Subodh C. Pal ${ }^{2}$, Deelip V. Derle ${ }^{2}$ \\ ${ }^{1}$ Department of Pharmacognosy, Sitabai Thite College of Pharmacy, Pune, Maharashtra, India, ${ }^{2}$ Department of \\ Pharmacognosy, MVP's College of Pharmacy, Nashik, Maharashtra, India
}

\begin{abstract}
Introduction: In the present study, fruit extracts of Momordica cochinchinensis (Cucurbitaceae) and Momordica balsamina (Cucurbitaceae) were investigated for analgesic activity by Eddy's hot plate and Tail immersion method. Materials and Methods: The extracts were prepared successively using powdered material with petroleum ether, ethanol, and water, and concentrated under vacuum and were evaluated for analgesic activity at three dose level $(100,200$, and $400 \mathrm{mg} / \mathrm{kg})$. Results and Discussion: In Eddy's hot plate method, oral administration of petroleum ether extracts of both the plants at the dose of $200 \mathrm{mg} / \mathrm{kg}(P<0.01)$ and $400 \mathrm{mg} / \mathrm{kg}(P<0.001)$ significantly reduced the thermal stimulation. Analgesic activity of petroleum ether extracts of both plants at the dose of $400 \mathrm{mg} / \mathrm{kg}$ after $90 \mathrm{~min}$ was comparable to standard drug pentazocine $(10 \mathrm{mg} / \mathrm{kg})$. In tail immersion method, petroleum ether extract at the dose of $100 \mathrm{mg} / \mathrm{kg}(P<0.05), 200 \mathrm{mg} / \mathrm{kg}$, and $400 \mathrm{mg} / \mathrm{kg}(P<0.01)$ and alcoholic extract at the dose of $200 \mathrm{mg} / \mathrm{kg}$ and $400 \mathrm{mg} / \mathrm{kg}(P<0.05)$ of both plant material has shown significant analgesic activity and was comparable to standard drug pentazocine $(10 \mathrm{mg} / \mathrm{kg})$ after $90 \mathrm{~min}$. Conclusion: It is concluded that petroleum ether extracts of both plant material have central analgesic effects.
\end{abstract}

Key words: Analgesic activity, Eddy's hot plate, Momordica balsamina, Momordica cochinchinensis, phytosterols, tail immersion

\section{INTRODUCTION}

$M$ Tomordica is a genus of about 60 species of annual or perennial climbers herbaceous or rarely small shrubs belonging to the family Cucurbitaceae, natives of tropical and subtropical Africa, Asia and Australia. ${ }^{[1,2]}$

Momordica cochinchinensis $(\mathrm{Gac})$ is a Southeast Asian fruit found throughout the region from Southern China to Northeastern Australia, mostly Vietnam and throughout India. It grows on dioecious vines and is usually collected from fence climbers or wild plants. The vines can be commonly seen growing on lattices at the entrances to rural homes or in gardens. It bears fruits annually and is found in local markets. The fruit becomes a dark orange color on ripening, and is typically round or oblong, maturing to a size of about $13 \mathrm{~cm}$ in length and $10 \mathrm{~cm}$ in diameter. The exterior skin is covered in small spines, while dark red interior consists of clusters of fleshy pulp and seeds. ${ }^{[3]}$ Gac fruit, M. cochinchinensis Spreng, is one of the special fruits containing extraordinarily high levels of carotenoids, especially $\beta$-carotene $(>16 \mathrm{mg} / 100 \mathrm{~g})$, and lycopene $\left(>50 \mathrm{mg} / 100 \mathrm{~g}\right.$ ), mainly in the red aril. ${ }^{[4]}$ Conventionally, Gac has been used as both food and medicine and promotes healthy vision by relief of dry eyes. It also possesses antioxidant, antimicrobial, and antidiabetic properties. The seeds are considered to be good for cough and pains in the chest..$^{[5-7]}$

Momordica balsamina Family: Cucurbitaceae is climber with bright green leaves bears striking orange to red spindleshaped ripe fruit. Shurb is fairly common and widespread in Malaya, Australia, West Asia, Africa, America, and India (Sind, Gujarat, and Deccan). Conventionally used as a purgative agent, purification of blood and dissipate

\section{Address for correspondence: \\ Mohan R. Agrawal, Department of Pharmacognosy, Sitabai Thite College of Pharmacy, Pune, Maharashtra, India. Tel.: +91-2138-222680/9860947093. \\ E-mail: agrawalmohan19@gmail.com}

Received: $15-05-2018$

Revised: $10-08-2018$

Accepted: 12-10-2018 
melancholia, stimulant, and gross humors. In Africa, as a medicinal plant for curing various diseases such as diabetes and malaria..$^{[5,8]}$

\section{MATERIALS AND METHODS}

\section{Plant Material}

The herbarium of the M. cochinchinensis and M. balsamina was authenticated by Botanical Survey of India, Pune and Veer Narmad South Gujrat University, Surat, respectively, and voucher specimens were deposited in the library.

\section{Preparation of Extracts}

Fruits of $M$. cochinchinensis and M. balsamina were extracted successively by Soxhlet extractor with petroleum ether and macerated with ethanol and water. All the extracts were stored in tightly closed glass bottles in refrigerator at $2-8^{\circ} \mathrm{C}$.

\section{Animals}

Male Wistar rats (200-250 g) and Swiss albino mice $(25-40 \mathrm{~g})$ were used and procured from National Toxicological Centre, Pune. The animals were maintained in colony cages at $25 \pm 20^{\circ} \mathrm{C}$, relative humidity $50-55 \%$ maintained under $12 \mathrm{~h}$ light and dark cycle $(6-10 \mathrm{~h}$ light and $18-6 \mathrm{~h}$ dark). The animals were fed with standard animal feed, and water was applied ad libitum. All animals were acclimatized to the laboratory conditions before experimentation.

\section{Acute Toxicity Studies}

Acute toxicity studies were carried out using the acute toxic class method as per the OECD guidelines 425. ${ }^{[9]}$ Acute toxicity for various plant extracts was carried out using groups of three Swiss Albino mice by administrating a dose of $2000 \mathrm{mg} / \mathrm{kg}$, in $1 \%$ carboxymethylcellulose (CMC) p.o., while the control group received only the vehicle. The groups were observed for mortality and behavioral changes during $48 \mathrm{~h}$.

\section{Preliminary Phytochemical Analysis of Extracts}

All the extracts were tested for the presence of various chemical constituents. ${ }^{[10,11]}$

\section{Analgesic Studies}

\section{Eddy's hot plate method}

Hot plate method developed by Woolfe and McDonalds ${ }^{[12,13]}$ was followed. Wistar rats $(n=6)$ were placed in Eddy's hot plate kept at a temperature of $55 \pm 0.5^{\circ} \mathrm{C}$. A cutoff time of
$30 \mathrm{~s}$ was fixed to avoid damage to the paw. The reaction time of response was recorded using a stopwatch. Control animals were treated with vehicle $(0.3 \% \mathrm{CMC}$, oral $)$ and test groups were pretreated with a single dose of 100,200 , and $400 \mathrm{mg} / \mathrm{kg}$ p.o. of petroleum ether, ethanol, and water extract of fruits of M. cochinchinensis and M. balsamina. Pentazocine $(10 \mathrm{mg} / \mathrm{kg})$ was used as a positive control. The latency was recorded before and after 30,60, 90, 120, and 180 min following oral administration of each extract. Percentage analgesia was calculated using the following formula.

$\%$ Analgesia $=$ Latency $($ test $)-$ Latency $($ control $) /$ Latency (test) $\times 100$

\section{Tail immersion method}

Wistar rats were administered orally with vehicle (0.3\% CMC, oral) $(3 \mathrm{ml} / \mathrm{kg})$, Pentazocine $(10 \mathrm{mg} / \mathrm{kg})$ as a standard and test groups with petroleum ether, ethanolic, and aqueous extracts of fruits of $M$. cochinchinensis and $M$. balsamina at the dose 100, 200, and $400 \mathrm{mg} / \mathrm{kg}$. The distal part of the tails of the animals was immersed in hot water maintained at $55.0 \pm 1.0^{\circ} \mathrm{C}$. The time taken to withdraw the tail was noted as reaction time. A cutoff time of $10 \mathrm{~s}$ was maintained at $55^{\circ} \mathrm{C}$ to prevent tissue damage. The reaction time was measured before and 30, 60, 90, and $120 \mathrm{~min}$ after treatment, respectively. Percentage of elongation was calculated using the following formula. ${ }^{[14]}$

Elongation $(\%)=$ Latency $($ test $)-$ Latency $($ control $) /$ Latency (test) $\times 100$

\section{Statistical Analysis}

All experimental data were expressed as the mean \pm standard error of the mean. Statistical analysis was carried out using one-way ANOVA followed by Dunnett's $t$-test and two-way ANOVA followed by Bonferroni Posttests. The values of $P<0.05$ were considered as statistical significant.

\section{RESULTS}

\section{Preliminary Phytochemical Screening}

The results of preliminary phytochemical screening of various extracts of fruits of $M$. chinchinensis and M. balsamina revealed the presence of glycosides, flavonoids, steroids, phenolic compounds, carotenoids, and carbohydrates [Table 1].

\section{Acute Toxicity}

All extracts of fruits of $M$. cochinchinensis and M. balsamina were evaluated for acute toxicity in mice by oral administration. No behavioral changes were observed after $4 \mathrm{~h}$. It was found that all the extracts were safe at the highest 
Table 1: Preliminary phytochemical screening of Momordica cochinchinensis and Momordica balsamina fruit extracts

\begin{tabular}{|c|c|c|c|c|c|c|}
\hline \multirow[t]{2}{*}{ Constituents } & \multicolumn{3}{|c|}{ Momordica cochinchinensis } & \multicolumn{3}{|c|}{ Momordica balsamina } \\
\hline & $\begin{array}{l}\text { Petroleum ether } \\
\text { (PEMC) }\end{array}$ & $\begin{array}{l}\text { Ethanolic } \\
\text { (AlcMC) }\end{array}$ & $\begin{array}{l}\text { Aqueous } \\
\text { (AqMC) }\end{array}$ & $\begin{array}{l}\text { Petroleum ether } \\
\text { (PEMB) }\end{array}$ & $\begin{array}{l}\text { Ethanolic } \\
\text { (AlcMB) }\end{array}$ & $\begin{array}{c}\text { Aqueous } \\
\text { (AqMB) }\end{array}$ \\
\hline Phytosterols & + & - & - & ++ & - & - \\
\hline Glycosides & - & + & - & - & + & - \\
\hline Carbohydrates & - & - & + & - & - & ++ \\
\hline Flavonoids & - & + & - & - & + & - \\
\hline Alkaloids & - & - & - & - & - & - \\
\hline Tannins & - & - & - & - & + & - \\
\hline Proteins & - & - & - & - & - & - \\
\hline Saponins & - & + & + & - & + & + \\
\hline Carotenoids & + & - & - & + & - & - \\
\hline Phenolic compounds & - & + & - & - & + & - \\
\hline
\end{tabular}

+: Presence, -: Absence

dose of $2000 \mathrm{mg} / \mathrm{kg}$ and no mortality was shown even after 14 days of extract administration. Moreover, no mortality was observed during the toxicity study.

\section{Analgesic Studies}

\section{Eddy's hot plate method}

Analgesic effects of petroleum ether, alcohol, and water extracts of fruits of $M$. cochinchinensis and M. balsamina evaluated by Eddy's hot plate method are shown in Figures 1 and 2, respectively. It revealed that oral administration of petroleum ether extracts of both the plants at the dose of $200 \mathrm{mg} / \mathrm{kg}(P<0.01)$ and $400 \mathrm{mg} / \mathrm{kg}(P<0.001)$ significantly reduced the thermal stimulation. Analgesic activity of petroleum ether extracts at the dose of $400 \mathrm{mg} / \mathrm{kg}$ of M. cochinchinensis (44.07\%) and M. balsamina (46.02\%) after 90 min was comparable to standard drug Pentazocine $(10 \mathrm{mg} / \mathrm{kg}) \quad(57.66 \%)$ [Table 2]. Alcoholic and water extracts at all doses were nonsignificant.

\section{Tail immersion method}

Extracts were subjected to evaluation of analgesic effects by tail immersion method [Figures 3 and 4]. Petroleum ether extract at the dose of $100 \mathrm{mg} / \mathrm{kg}(P<0.05)$, $200 \mathrm{mg} / \mathrm{kg}$, and $400 \mathrm{mg} / \mathrm{kg}(P<0.01)$ and alcoholic extract at the dose of $200 \mathrm{mg} / \mathrm{kg}$ and $400 \mathrm{mg} / \mathrm{kg}(P<0.05)$ of fruits of $M$. cochinchinensis and $M$. balsamina have shown significant analgesic activity, while alcoholic extract at the dose of $100 \mathrm{mg} / \mathrm{kg}$ and all doses of water extract were non significant. Analgesic activity of petroleum ether extracts at the dose of $400 \mathrm{mg} / \mathrm{kg}$ of $M$. cochinchinensis (40.57\%) and M. balsamina (43.82\%) after 90 min was comparable to standard drug Pentazocine $(10 \mathrm{mg} / \mathrm{kg}) \quad(44.83 \%)$ [Table 3].

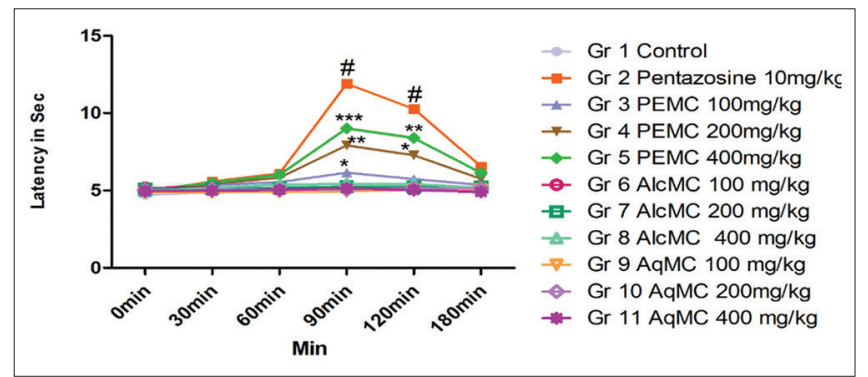

Figure 1: Analgesic activity of Momordica cochinchinensis by Eddy's hot plate method. Values are the mean \pm standard error of the mean from 6 animals in each group. Two-way ANOVA followed by Bonferroni posttests. \# $<0.001,{ }^{*} P<0.05$, ${ }^{* *} P<0.01$, and ${ }^{* * *} P<0.001$ when compared to control group were considered as significant.

\section{DISCUSSION}

The universal role of the plants in the treatment of diseases is exemplified by their role in the all major system of medicine. Herbal medicines are the oldest form of health care known to mankind and are used by all cultures throughout history. ${ }^{[15]}$ Plants used in traditional medicine contain wide variety of chemical constituents that can be used to treat chronic and acute diseases. ${ }^{[16]}$ Preliminary phytochemical screening of petroleum ether, ethanolic and water extracts of fruits of $M$. cochinchinensis and M. balsamina were carried out and revealed the presence of glycosides, flavonoids, steroids, phenolic compounds, carotenoids, and carbohydrates.

Acute toxicity study showed that all the extracts of both the plants caused no mortality up to a dose of $2000 \mathrm{mg} / \mathrm{kg}$, and no behavioral changes observed in any group. Based on these data three doses, that is, $100 \mathrm{mg} / \mathrm{kg}, 200 \mathrm{mg} / \mathrm{kg}$, and $400 \mathrm{mg} / \mathrm{kg}$ of each extract were selected for further study. In the present study, analgesic activity of petroleum ether, ethanolic, and water extracts of fruits of $M$. cochinchinensis 
Agrawal, et al.: Analgesic activity of Momordica cochinchinensis and Momordica balsamina fruit extract

Table 2: Comparative effects of petroleum ether extracts on the latency of rats exposed to hot plate at $90 \mathrm{~min}$

\begin{tabular}{lcclcc} 
Treatment & Mean latency time & $\%$ Protection & Treatment & Mean latency time & \% Protection \\
\hline Vehicle control & $5.042 \pm 0.095$ & -- & Vehicle control & $5.210 \pm 0.060$ & -- \\
Pentazocine $(10 \mathrm{mg} / \mathrm{kg})$ & $11.91 \pm 0.240^{*}$ & 57.66 & Pentazocine $(10 \mathrm{mg} / \mathrm{kg})$ & $12.36 \pm 0.3216^{\#}$ & 58.57 \\
PEMC $100 \mathrm{mg} / \mathrm{kg}$ & $6.158 \pm 0.181^{\star}$ & 18.12 & PEMB $100 \mathrm{mg} / \mathrm{kg}$ & $6.463 \pm 0.1396^{\star}$ & 19.38 \\
PEMC $200 \mathrm{mg} / \mathrm{kg}$ & $7.925 \pm 0.201^{\star \star}$ & 36.37 & PEMB $200 \mathrm{mg} / \mathrm{kg}$ & $8.762 \pm 0.068^{\star *}$ & 40.53 \\
PEMC $400 \mathrm{mg} / \mathrm{kg}$ & $9.015 \pm 0.155^{\star \star *}$ & 44.07 & PEMB 400 mg/kg & $9.652 \pm 0.116^{\star *}$ & 46.02 \\
\hline
\end{tabular}

Each value is the mean \pm SEM of six determinations. ${ }^{*} P<0.05$, ${ }^{* *} P<0.01,{ }^{* *} P<0.001$, Two-way ANOVA followed by Bonferroni posttests, when compared to control group. SEM: Standard error of the mean

Table 3: Comparative effect of petroleum ether extracts of Momordica cochinchinensis and Momordica balsamina on tail withdrawal reflex of rats induced by tail immersion method after 90 min of drug treatment

\begin{tabular}{lcclcc} 
Treatment & $\begin{array}{c}\text { Mean } \\
\text { reaction time }\end{array}$ & \% Protection & Treatment & $\begin{array}{c}\text { Mean reaction } \\
\text { time }\end{array}$ & $\%$ Protection \\
\hline Vehicle control & $5.960 \pm 0.228$ & -- & Vehicle control & $5.848 \pm 0.160$ & -- \\
Pentazocine $(10 \mathrm{mg} / \mathrm{kg})$ & $10.31 \pm 0.150^{*}$ & 42.19 & Pentazocine $(10 \mathrm{mg} / \mathrm{kg})$ & $10.60 \pm 0.102^{\#}$ & 44.83 \\
PEMC $100 \mathrm{mg} / \mathrm{kg}$ & $8.082 \pm 0.145^{*}$ & 26.25 & PEMB $100 \mathrm{mg} / \mathrm{kg}$ & $8.410 \pm 0.199^{\star *}$ & 30.46 \\
PEMC $200 \mathrm{mg} / \mathrm{kg}$ & $9.197 \pm 0.118^{\star *}$ & 35.19 & PEMB 200 $\mathrm{mg} / \mathrm{kg}$ & $9.410 \pm 0.150^{\star *}$ & 37.85 \\
PEMC $400 \mathrm{mg} / \mathrm{kg}$ & $10.03 \pm 0.131^{* *}$ & 40.57 & PEMB 400 mg/kg & $10.41 \pm 0.185^{\star * *}$ & 43.82 \\
\hline
\end{tabular}

Each value is the mean \pm SEM of six determinations. ${ }^{\star} P<0.05,{ }^{\star \star} P<0.01,{ }^{\star \star \star} P<0.001$, Two-way ANOVA followed by Bonferroni posttests, when compared to control group. SEM: Standard error of the mean

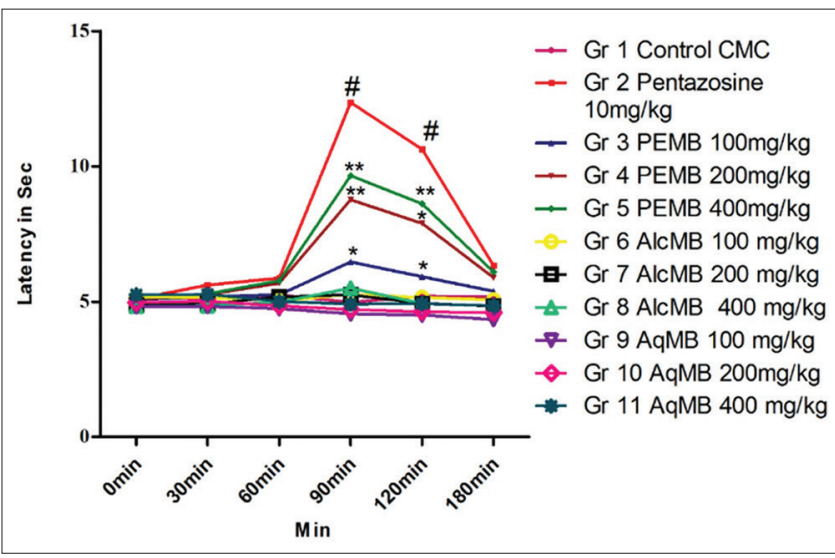

Figure 2: Analgesic activity of Momordica balsamina by Eddy's hot plate method. Values are the mean \pm standard error of the mean from 6 animals in each group. Two-way ANOVA followed by Bonferroni posttest. \# $<0.001$, ${ }^{*} P<0.05$, ${ }^{* *} P<0.01$, and ${ }^{* \star *} P<0.001$ when compared to control group were considered as significant

and $M$. balsamina was evaluated by two models, that is, Eddy's hot plate method and tail immersion method.

In Eddy's hot plate method, there is marked central analgesic effect as evidenced by significant increase in reaction time. Results depicted that petroleum ether extracts of both plant materials have shown increase in latency period in a dosedependent manner. Petroleum ether extracts at the dose of $400 \mathrm{mg} / \mathrm{kg}$ after $90 \mathrm{~min}$ significantly reduced the pain compared to Pentazocine; this central analgesic effect may be due to inhibition of prostaglandins synthesis and presence of

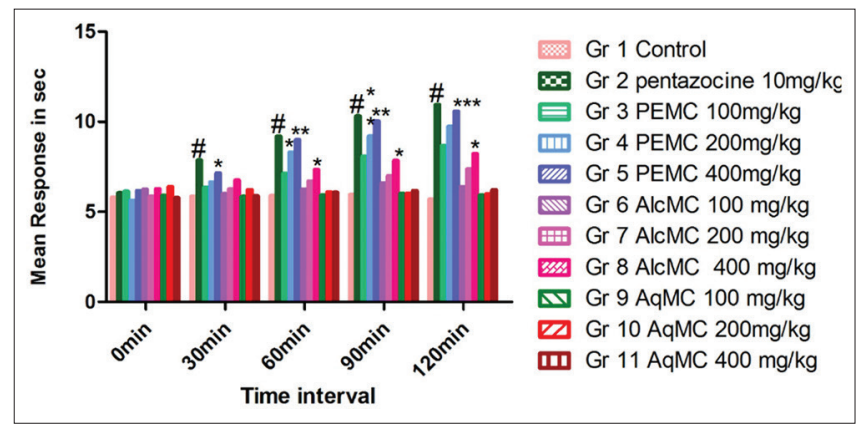

Figure 3: Analgesic activity of Momordica cochinchinensis by tail immersion method. Values are the mean \pm standard error of the mean from 6 animals in each group. Two-way ANOVA followed by Bonferroni posttests. \#<0.001, ${ }^{*} P<0.05,{ }^{* *} P<0.01$, and ${ }^{* \star *} P<0.001$ when compared to control group were considered as significant

phytosterols in these extracts. Alcoholic and aqueous extracts were found to be ineffective.

Tail immersion method is the second most commonly used test to assess analgesics. Substance $\mathrm{P}$ is released in excessive quantities due to the stimulation of nonmyelinated $\mathrm{C}$ fibers of rats' tail after the application of thermal heat serving as noxious stimuli. Narcotic analgesics like Pentazocine are potential agonist of $\mu, \kappa$, and $\delta$ receptors. These receptors are specific for endogenous narcotics such as endorphins and encephalin. After binding to these receptors, narcotic analgesics antagonize the action of substance $\mathrm{P}$ in the central nervous system (CNS) by producing post-synaptic inhibitory action on interneuron, which processes the nociceptive information 


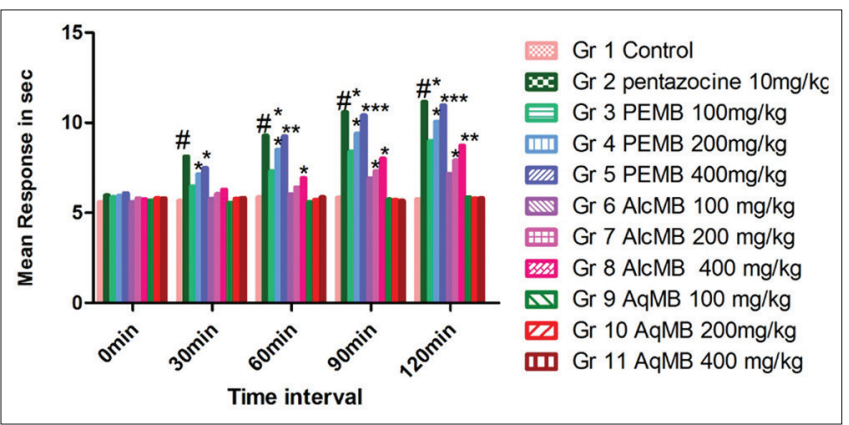

Figure 4: Analgesic activity of Momordica balsamina by tail immersion method. Values are the mean \pm standard error of the mean from 6 animals in each group. Two-way ANOVA followed by Bonferroni posttests. \# $<0.001$, ${ }^{*} P<0.05$, ${ }^{\star *} P<0.01$, and ${ }^{* * *} P<0.001$ when compared to control group were considered as significant

to be transmitted to the CNS. ${ }^{[14]}$ Petroleum ether and alcoholic extracts of both plants were effective in increasing reaction time in dose-dependent manner. Petroleum ether extracts at the dose of $400 \mathrm{mg} / \mathrm{kg}$ after $90 \mathrm{~min}$ significantly reduced the pain compared to Pentazocine. As our petroleum ether extracts of M. cochinchinensis and M. balsamina showed significant analgesic activity in the thermal heat method, it can be assumed that the extracts could act by a central anti-nociceptive mode like that of Pentazocine.

\section{CONCLUSION}

It was concluded from the present study that petroleum ether extracts of fruits of M. cochinchinensis and M. balsamina have significant central analgesic activity that may attribute to more amount of phytosterols present in these plants. However, further work has to be done to isolate the compounds responsible for these activities.

\section{ACKNOWLEDGMENT}

The authors are highly thankful to MVP's College of Pharmacy, Nashik, for providing all the facilities for the present study. The authors are also thankful to Principal, Sitabai Thite College of Pharmacy, Shirur, for their continuous support.

\section{REFERENCES}

1. Rasul MG, Hiramatsu M, Okubo H. Genetic relatedness (diversity) and cultivar identification by randomly amplified polymorphic DNA (RAPD) markers in teasle gourd (Momordica dioica Roxb.). Sci Hortic 2007;111:271-9.

2. Ullah M, Chy FK, Sarkar SK. Nutrient and phytochemical analysis of four varieties of bitter guard (Momordica charantia) grown in Chittagong Hill tracts of Bangladesh. Asian J Agric Res 2011;5:1-8.

3. Nadkarnis KM, Nadkarnis AK. Indian Material Medica. Vol. 2. Bombay: Popular Publication; 2009. p. 805.

4. Kha TC, Nguyen MH, Roach PD. Effects of spray drying conditions on the physicochemical and antioxidant properties of the Gac (Momordica cochinchinensis) fruit aril powder. J Food Eng 2010;98:385-92.

5. Kirtikar KR, Basu BD. Indian Medicinal Plants. Vol. 2. Dehradun: International Book publisher; 2005. p. 1132-1137.

6. Orient Longman. Indian Medicinal Plant. a Compendium of 500 Species. Vol. 4. Hyderabad: Orient Longman; 1994. p. 48.

7. Mai HC, Truong V, Haut H, Debaste F. Impact of limited drying on Momordica cochinchinensis Spreng. Aril carotenoids content and antioxidant activity. J Food Eng 2013;118:358-64.

8. Amaral L, Ramalhete C, Spengler G, Martins A, Martins M, Viveiros M, et al. Inhibition of efflux pumps in Meticillin-resistant Staphylococcus aureus and Enterococcus faecalis resistant strains by triterpenoids from Momordica balsamina. Int J Antimicrob Agents 2011;37:70-4.

9. OECD Guidelines for Testing Chemicals. Guidelines 423. Acute Oral Toxicity-Acute Toxic class Method. Paris: OECD Guidelines for Testing Chemicals; 1996.

10. Khandelwal KR. Practical Pharmacognosy. Vol. 9. Pune: Nirali Prakashan; 2008. p. 139-68.

11. Kokate CK, Purohit AP, Gokhale SB. Pharmacognosy Book. Pune: Nirali Publication; 2003. p. 219.

12. Woolfe PK, MacDonald AD. The evaluation of the analgesic action of pethidine hydrochloride (DEMEROL). J Pharm Exp Ther 1944;80:300-7.

13. Malairajan P, Gopalakrishnan G, Narasimhan S, Veni K. Analgesic activity of some Indian medicinal plants. J Ethnopharm 2006;106:425-8.

14. Sharma S, Kumavat R, Kumar S. Evaluation of analgesic activity of various extracts of sida Tiagii Bhandari. Acta Pol Pharm Drug Res 2012;69:1103-9.

15. Trease GE, Evans WC. Pharmacognosy. London: Macmillan Publishers Ltd.; 1985. p. 3-4.

16. Sermanni M. Evaluation of phytochemical and antibacterial activity of Pedalium murex Linn. Root. Int Res J Pharm 2011;2:131-4.

Source of Support: Nil. Conflict of Interest: None declared. 